Check for updates

Cite this: RSC Adv., 2017, 7, 21144

DOI: 10.1039/c7ra90056b

www.rsc.org/advances

\title{
Retraction: Cell orientation, proliferation, and differentiation on poly(L-lactide) spherulites
}

\author{
F. Zou, ${ }^{a}$ F. Z. Lu, ${ }^{a}$ X. S. Ma, ${ }^{a}$ D. W. He, ${ }^{b}$ T. T. Tang, ${ }^{c}$ X. L. Xia, ${ }^{a}$ J. Y. Jiang ${ }^{\star a}$ and Y. F. Niu ${ }^{\star b}$
}

Retraction of 'Cell orientation, proliferation, and differentiation on poly(L-lactide) spherulites' by F. Zou et al., RSC Adv., 2016, 6, 57396-57402.

We the authors, hereby wholly retract this RSC Advances article due to the unattributed and misleading copying of figures, and a lack of reproducibility in some of the published data, which significantly undermines the published conclusions.

The following figures have been copied from published papers; Fig. 1a is from Fig. 7a in ref. 1, Fig. 1b is from Fig. 9 in ref. 2, and Fig. $7 \mathrm{a}$ and $\mathrm{b}$ are from Fig. 3 in ref. 3 .

Further to this, the authors have established that the data in Fig. 4, 5 and 6 cannot be reproduced and therefore should not be relied upon. As a result, the conclusions relating to adhesion and cell proliferation are no longer supported.

The authors would like to apologise for any consequent inconvenience to authors and readers.

Signed: F. Zou, X. S. Ma, D. W. He, T. T. Tang, X. L. Xia, J. Y. Jiang and Y. F. Niu.

$4^{\text {th }}$ February 2017.

F. Z. Lu (co-author to the original paper) could not be contacted.

Retraction endorsed by Andrew Shore, Executive Editor, RSC Advances.

\section{References}

1 V. S. D. Voet, G. O. R. Alberda van Ekenstein, N. L. Meereboer, A. H. Hofman, G. t. Brinke and K. Loos, Polym. Chem., 2014, 5, 22192230.

2 F. Wu, C-. L. Huang, J-. B. Zeng, S-. L. Li and Y-. Z. Wang, RSC Adv., 2014, 4, 54175-54186.

3 W. Tang, D. Lin, Y. Yu, H. Niu, H. Guo, Y. Yuan and C. Liu, Acta Biomaterialia, 2016, 32, 309-323.

a Department of Orthopaedics, Huashan Hospital, Fudan University, Shanghai, 200040, China. E-mail: zillion-faculty@126.com ${ }^{b}$ Department of Orthopaedics, Changhai Hospital, The Second Military Medical University, Shanghai 200433, China. E-mail: nyflying126@126.com

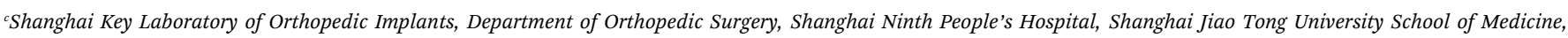
Shanghai 200011, China 